\title{
Studi Kasus: Asuhan Keperawatan Jiwa Pada Ny. R Dengan Risiko Perilaku Kekerasan
}

\author{
Fanny Fadillah \\ Fadillahfanny421@gmail.com
}

\section{BAB I \\ PENDAHULUAN}

\subsection{Latar Belakang}

Skizofrenia merupakan penyakit kronis, parah, dan melumpuhkan, gangguan otak yang di tandai dengan pikiran kacau, waham, delusi, RPK, dan perilaku aneh atau katatonik (Pardede, \& Laia. 2020). Skizofrenia adalah gangguan jiwa yang dapat berakhir dengan hilanngya dengan nyawa seseorang. Dalam penanganan penyakit ini karena jiwa yang terganggu maka di butuhkan adalah terapi, rehabilitasi serta dengan konseling. Upaya terbesar untuk penangan penyakit gangguan jiwa terletak pada keluarga dan masyarakat, dalam hal ini terapi terbaik adalah bentuk dukungan keluarga dalam mencegah kambuhnya penyakit skizofrenia (Pitayanti, \& Hartono, 2020). Skizofrenia merupakan suatu gangguan jiwa berat yang bersifat berat dan kronis yang menyerang 20 juta orang di seluruh dunia (WHO, 2019). Prevalensi penderita skizofrenia pada tahun 2017 berjumlah lebih dari 450 juta orang diseluruh dunia (WHO, 2018). Di Indonesia, prevelensi penderita skizofrenia mencapai 0,3 sampai $1 \%$ dan biasanya mulai tampak pada usia 18 sampai 45 tahun. Jika jumlah penduduk yang ada di Indonesia mencapai 200 jiwa maka dapat diperkirakan sekitar 2 juta orang menderita skizofrenia (Sutejo, 2017).

Skizofrenia menimbulkan distorsi pikiran, distorsi persepsi, emosi, dan tingkah laku sehingga pasien dengan skizofrenia memiliki resiko lebih tinggi berperilaku agresif dimana perubahan perilaku secara dramatis terjadi dalam 
beberapa hari atau minggu. Pasien skizofrenia sering dikaitkan dengan perilaku yang dapat membahayakan diri sendiri maupun orang lain ataupun berisiko juga dengan lingkungan sekitarnya, baik secara fisik, emosional, seksual, dan verbal yang disebut sebagai risiko perilaku kekerasan ( Pardede, Simanjuntak \& Laia, 2020 )

Perilaku kekerasan merupakan salah satu respon terhadap streesor yang dihadapi oleh seseorang, respon ini dapat menimbulkan kerugian baik kepada diri sendiri, orang lain, maupun lingkungan. Seseorang yang mengalami perilaku kekerasan sering menunjukan perubahan perilaku seperti mengancam, gaduh, tidak bisa diam, mondar-mandir, gelisah, intonasi suara keras, ekspresi tegang, bicara dengan semangat, agresif, nada suara tinggi dan bergembira secara berlebihan. Pada seseorang yang mengalami resiko perilaku kekerasan mengalami perubahan adanya penurunan kemampuan dalam memecahkan masalah, orientasi terhadap waktu, tempat dan orang serta gelisah (Pardede, Siregar, \& Halawa, 2020). Risiko mencederai merupakan suatu tindakan yang memungkinkan dapat melukai atau membahayakan diri sendiri, orang lain, dan lingkungan sehingga masalah yang terjadi pada pasien parilaku kekerasan akan melibatkan keluarga (Suryeti 2017).

Survey awal pada pembuatan asuhan keperawatan pada skizofrenia ini dilakukan di Yayasan Pemenag Jiwa Sumatera dengan pasien Resiko Perilaku Kekerasan dengan pasien nama inisial Ny. R, klien datang ke yayasan klien suka marah-marah dirumah dan suka berbicara sendir.

\subsection{Rumusan Masalah}

Berdasarkan latar belakang masalah tersebut maka dapat dirumuskan masalah saebagai berikut : Bagaimana Memberikan Asuhan Keperawatan Jiwa Pada Ny.R dengan Risiko Perilaku Kekerasan di Yayasan Pemenang Jiwa 


\subsection{Tujuan Penulisan}

\subsubsection{Tujuan umum}

Penulis mampu memberikan asuhan keperawatan jiwa pada Ny.R dengan Risiko Perilaku Kekerasan di Yayasan Pemenang Jiwa

\subsubsection{Tujuan khusus}

a. Mahasiswa mampu mengetahui defenisi, tanda \& gejala,faktor penyebab, mekanisme koping, penatalaksanaan pada pasien dengan Risiko Perilaku Kekerasan

b. Mahasiswa mampu melakukan pengkajian pada pasien dengan Risiko Perilaku Kekerasan

c. Mahasiswa mampu menegakkan diagnosa atau masalah keperawatan pada Ny.R dengan Risiko Perilaku Kekerasan.

d. Mahasiswa mampu menetapkan intervensi keperawatan secara menyeluruh pada Ny.R dengan Risiko Perilaku Kekerasan.

e. Mahasiswa mampu melakukan tindakan keperawatan yang nyata pada Ny.R dengan Risiko Perilaku Kekerasan.

f. Mahasiswa mampu mengevaluasi sebagai tolak ukur guna menerapkan asuhan keperawatan pada Ny.R dengan Risiko Perilaku Kekerasan.

g. Mahasiswa mampu mendokumentasikan asuhan keperawatan pada Ny.R dengan Risiko Perilaku Kekerasan 


\section{BAB 2 \\ TINJUAN TEORITIS}

\subsection{Konsep Risiko Perilaku Kekerasan}

\subsubsection{Defenisi}

Perilaku kekerasan adalah merupakan bentuk kekerasan dan pemaksaan secara fisik maupun verbal ditunjukkan kepada diri sendiri maupun orang lain. Perilaku kekerasan adalah salah satu bentuk perilaku yang bertujuan untuk melukai seseorang secara fisik maupun psikologi. Perilaku agresif dan perilaku kekerasan seringdipandang sebagai rentang dimana agresif verbal di suatu sisi dan perilaku kekerasan (violence) di sisi yanglain. Suatu keadaan yang menimbulkan emosi, perasaan frustasi, benci atau marah.Hal ini akan mempengaruhi perilaku seseorang. Berdasarkan keadaan emosi secara mendalam tersebut terkadang perilaku menjadi agresif atau melukai karena penggunaan koping yang kurang bagus.(Kandar \& Iswanti, 2019).

\subsubsection{Tanda Dan Gejala}

Tanda dan gejala perilaku kekerasan berdasarkan standar asuhan keperawatan jiwa dengan masalah risiko perilaku kekerasan, (Pardede, 2020) :

\section{Subjektif}

a. Mengungkapkan perasaan kesal atau marah.

b. Keinginan untuk melukai diri sendiri, orang lain dan lingkungan.

c. Klien suka membentak dan menyerang orang lain. 


\section{Objektif}

a. Mata melotot/pandangn tajam.

b. Tangan mengepal dan Rahang mengatup.

c. Wajah memerah.

d. Postur tubuh kaku.

e. Mengancam dan Mengumpat dengan kata-kata kotor

f. Suara keras.

g. Bicara kasar, ketus.

h. Menyerang orang lain dan Melukai diri sendiri/orang lain.

i. Merusak lingkungan.

j. Amuk/agresif.

\subsubsection{Rentang Respon Marah}

Adaptif

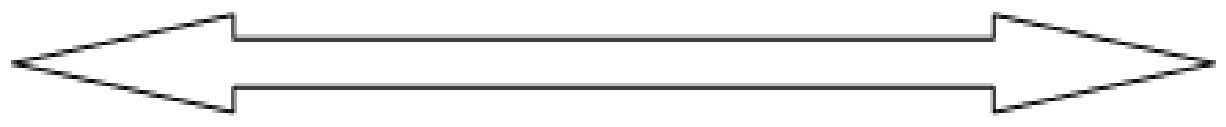

Asertif

Frustasi Pasif

Agresif

Amuk

\section{Gambar 2.1Rentang Respon Marah}

Sumber : (Stuart \& Sundeen, 1998)

Keterangan :

1. Assertif adalah mengungkapkan marah tanpa menyakiti, melukai perasaan orang lain, atau tanpa merendahkan harga diri orang lain.

2. Frustasi adalah respon yang timbul akibat gagal mencapai tujuan atau keinginan. Frustasi dapat dialami sebagai suatu 
ancaman dan kecemasan. Akibat dari ancaman tersebut dapat menimbulkan kemarahan.

3. Pasif adalah respon dimana individu tidak mampu mengungkapkan perasaan yang dialami.

4. Agresif merupakan perilaku yang menyertai marah namun masih dapat dikontrol oleh individu. Orang agresif bisaanya tidak mau mengetahui hak orang lain. Dia berpendapat bahwa setiap orang harus bertarung untuk mendapatkan kepentingan sendiri dan mengharapkan perlakuan yang sama dari orang lain.

5. Amuk adalah rasa marah dan bermusuhan yang kuat disertai kehilangan control diri. Pada keadaan ini individu dapat merusak dirinya sendiri maupun terhadap orang lain.

\subsubsection{Etiologi}

Penyebab dari perilaku kekerasan bukan terdiri cuman satu faktor tetapi termasuk juga faktor keluarga, media, teman, lingkungan, biologis. Perilaku kekerasan dapat menimbulkan dampak seperti gangguan psikologis, merasa tidak aman, tertutup, kurng percaya diri, resiko bunuh diri, depresi, harga diri rendah, ketidak berdayaan, isolasi sosial (Putri, Arif \& Renidayati 2020).

Menurut Direja (2016), ada beberapa faktor penyebab perilaku kekerasan seperti :

1. Faktor predisposisi

Faktor pengalaman yang dialami tiap orang yang merupakan faktor predisposisi, artinya mungkinterjadi atau mungkin tidak terjadi perilaku kekerasan jika faktor berikut di alami oleh individu : 


\section{a. Psikologis}

Kegagalan yang dialami dapat menimbulkan frustasi yang kemudian menyenagkan atau perasaan ditolak, dihina, dianiaya, atau sanksi penganiayaan.

b. Perilaku reinforcement

Yang diterima saat melakukan kekerasan, dirumah atau di luar rumah, semua aspek ini menstimulasi individu mengadopsi perilaku kekerasan.

c. Teori psikoanalitik

Menjelaskan bahwa tidak terpenuhinya ego dan membuat konsep diri yang rendah. Agresi dapat meningkatkan citra diri serta memberikan arti dalam hidupnya.

2. Faktor presipitasi Secara umum seseorang akan marah jika dirinya merasa terancam, baik injuri fisik, psikis, atau ancaman konsep diri. Faktor pencetus sebagai berikut:

a. Klien : kelemahan fisik, keputusan, ketidakberdayaan, kehidupan yang penuh agresif dan masa lalu yang tidak menyenangkan.

b. Interaksi : penghinaan, kekerasan, kehilangan orang yang berarti, konflik, merasa terancam baik internal maupun eksternal.

\subsubsection{Penatalaksanaan}

Penatalaksaan perilaku kekerasan bisa juga dengan melakukan terapi restrain. Restrain adalah aplikasi langsung kekuatan fisik pada individu, tanpa injin individu tersebut, untuk mengatasi kebebasan gerak, terapi ini melibatkan penggunaan alat mekanis atau manual untuk membatasi mobilitas fisik pasien. Terapi restraindapat 
diindikasikan untuk melindungi pasien atau orang lain dari cidera pada saat pasien lagi marah ataupun amuk (Hastuti, Agustina, \& Widiyatmoko 2019).

Tindakan yang dilakukan perawat untuk mengatasi resiko perilaku kekerasan yaitu melakukan Strategi Pelaksanaan (SP) yang dilakukan oleh klien dengan perilaku kekerasan adalah diskusi mengenai cara mengontrol perilaku kekerasan secara fisik, obat, verbal, dan spiritual. Mengontrol perilaku kekerasan secara fisik dapat dilakukan dengan cara latihan tarik nafas dalam, dan pukul kasur atau bantal. Mengontrol secara verbal yaitu dengan cara menolak dengan baik, meminta dengan baik, dan mengungkapka dengan baik. Mengontrol perilaku kekerasan secara spiritual dengan cara shalat dan berdoa. Serta mengontrol perilaku kekerasan dengan minum obat secara teratur dengan prinsip lima benar (benar klien, benar nama obat, benar cara minum obat, benar waktu minum obat, dan benar dosis obat), (Sujarwo \& Livana, 2018).

\subsection{Konsep Asuhan Keperawatan Jiwa}

\subsubsection{Pengkajian Keperawatan}

1. Identitas

Riwayat ketidakjelasan nama atau identitas serta pendidikan yang rendah, atau riwayat putus sekolah yang mengakibatkan perkembangan kurang efektif. Status sosial tuna wisma, kehidupan terisolasi (kehilangan kontak sosial, misal pada lansia). Agama dan keyakinan klien tidak bisa menjelaskan aktivitas keagamaan secara rutin (Mellia Trisyani Putri, 2020). 
2. Alasan masuk

Biasanya klien masuk dengan alasan sering mengamuk tanpa sebab, memukul, membanting, mengancam, menyerang orang lain, melukai diri sendiri, mengganggu lingkungan, bersifat kasar dan pernah mengalami gangguan jiwa dimasa lalu kambuh karena tidak mau minum obat secara teratur (Keliat,2016).

\section{Faktor Predisposisi}

a) Biasanya klien pernah mengalami gangguan jiwa pada masa lalu dan pernah dirawat atau baru pertama kali mengalami gangguan jiwa (Parwati, Dewi \& Saputra 2018).

b) Biasanya klien berobat untuk pertama kalinya kedukun sebagai alternative serta memasung dan bila tidak berhasil baru di bawa kerumah sakit jiwa.

c) Trauma. Biasnya klien pernah mengalami atau menyaksikan penganiayaan fisik, seksual, penolakan, dari lingkungan.

d) Biasanya ada anggota keluarga yang mengalami gangguan jiwa, kalau ada hubungan dengan keluarga, gejala, pengobatan dan perawatan.

e) Biasanya klien pernah mengalami pengalaman masa lalu yang tidak menyenangkan misalnya, perasaan ditolak, dihina, dianiaya, penolakan dari lingkungan

4. Fisik

Pengkajian fisik

a) Ukur dan observasi tanda-tanda vital seperti tekanan darah akan bertambah naik, nadi cepat, suhu, pernapasan terlihat cepat.

b) Ukur tinggi badan dan berat badan. 
c) Yang kita temukan pada klien dengan prilaku kekerasan pada saat pemeriksaan fisik (mata melotot, pandangan tajam, tangan mengepal, rahang mengatup, wajah memerah)

d) Verbal (mengancam, mengupat kata-kata kotor, berbicara kasar dan ketus).

\section{Psikososial}

a) Genogram

Genogram dibuat 3 generasi keatas yang dapat menggambarkan hubungan klien dengan keluarga. Tiga generasi ini dimaksud jangkauan yang mudah diingat oleh klien maupun keluarga apa disaat pengkajian.

b) Konsep diri

Biasanya ada anggota tubuh klien yang tidak disukai klien yang mempengaruhi keadaan klien saat berhubungan dengan orang lain sehingga klien merasa terhina, diejek dengan kondisinya tersebut.

c) Identitas

Biasanya pada klien dengan prilaku kekerasan tidak puas dengan pekerjaannya, tidak puas dengan statusnya, baik disekolah, tempat kerja dan dalam lingkungan tempat tinggal

d) Harga diri

Biasanya klien dengan risiko prilaku kekerasan hubungan dengan orang lain akan terlihat baik, harmoni sata terdapat penolakan atau klien merasa tidak berharga, dihina, diejek dalam lingkungan keluarga maupun diluar lingkungan keluarga. 
e) Peran diri

Biasanya klien memiliki masalah dengan peranatau tugas yang diembannya dalam keluarga, kelompok atau masyarakat dan biasanya klien tidak mampu melaksanakan tugas dan peran tersebut dan merasa tidak berguna.

f) Ideal diri

Biasanya klien memilki harapan yang tinggi terhadap tubuh, posisi dan perannya baik dalam keluarga, sekolah, tempat kerja dan masyarakat.

6. Hubungan social

a) Orang yang berarti Tempat mengadu, berbicara

b) Kegiatan yang diikuti klien dalam masyarakat dan apakah klien berperan aktif dalam kelompok tersebut

c) Hambatan dalam berhubungan dengan orang lain/tingkat keterlibatan klien dalam hubungan masyarakat.

7. Spiritual

a) Nilai dan keyakinan

Biasanya klien mengatakan bahwa dia tidak mengalami gangguan jiwa.

b) Kegiatan ibadah

c) Biasaya dalam selama sakit klien jarang melakukan ibadah.

8. Status mental

a) Penampilan. 
b) Biasanya penampilan klien kotor.

c) Pembicaraan.

d) Biasanya pada klien prilaku kekerasan pada saat dilakukan pengkajian bicara cepat,keras, kasar, nada tinggi dan mudah tersinggung.

e) Aktivitas motoric

f) Biasanya aktivitas motoric klien dengan prilaku kekerasan akan terlihat tegang, gelisah, gerakan otot muka berubah-ubah, gemetar, tangan mengepal, dan rahang dengan kuat.

g) Alam perasaan

Biasanya akan merasa sedih dan menyesali apa yang telah dilakukan

h) Efek

Biasanya klien mudah tersinggung dan sering marahmarah tanpa sebab

i) Interaksi selama wawancara

Biasanya klien dengan risiko prilaku kekerasan akan terlihat bermusuhan, curiga, tidak kooperatif, tidak mau menatap lawan bicara dan mudah tersinggung.

j) Persepsi

Biasanya klien dengan prilaku kekerasan masih dapat menjawab pertanyaan dengan jelas.

k) Isi Pikir

Biasanya klien meyakini dirinya tidak sakit, dan baikbaik saja.

1) Tingkat kesadaran

Biasanya klien prilaku kekerasan kadang tampak bingung,

m) Memori 
Biasanya klien diwaktu wawancara dapat mengingat kejadian yang terjadi dan mengalami gangguan daya ingat jangka panjang.

n) Kemampuan penilaian

Biasanya klien mengalami kemampuan penilaian ringan dan sedang dan tidak mampu mengambil keputusan

o) Daya fikir diri

Biasanya klien mengingkari penyakit yang dideritanya

9. Kebutuhan persiapan pulang

a) Makan

Biasanya klien tidak mengalami perubahan

b) $\mathrm{BAB} / \mathrm{BAK}$

Biasanya klien dengan risiko prilaku kekerasan tidak ada gangguan

c) Mandi

Biasanya klien jarang mandi, tidak menyikat gigi, jarang mencuci rambut dan bercukur atau berhias. Badan klien sangat bau dan kotor, dan klien hanya melakukan kebersihan diri jika disuruh.

d) Berpakaian

Biasanya klien jarang mengganti pakaian, dan tidak mau berdandan. Klien tidak mampu mengenakan pakaian dengan sesuai dan klien tidak mengenakan alas kaki

e) Istirahat dan tidur

Biasanya klien tidak melakukan persiapan sebelum tidur, seperti: menyikat gigi, cucu kaki, berdoa. Dan sesudah tidur seperti: merapikan tempat tidur, mandi atau cuci muka dan menyikat gigi. Frekuensi tidur klien 
berubah-ubah, kadang nyenyak dan kadang gaduh atau tidak tidur.

f) Penggunaan obat

Biasanya klien mengatakan minum obat 3 kali sehari dan klien tidak mengetahui fungsi obat dan akibat jika putus minum obat.

g) Pemeliharaan kesehatan

Biasanya klien tidak memperhatikan kesehatannya, dan tidak peduli tentang bagaimana cara yang baik untuk merawat dirinya.

h) Aktifitas didalam rumah

Biasanya klien mampu merencanakan, mengolah, dan menyajikan makanan, merapikan rumah, mencuci pakaian sendiri dan mengatur biaya sehari-hari.

10. Mekanisme koping

Biasanya klien menggunakan respon maldaptif yang ditandai dengan tingkah laku yang tidak terorganisir, marah-marah bila keinginannya tidak terpenuhi, memukul anggota keluarganya, dan merusak alat-alat yg ada dirumah.

11. Masalah psikologis dan lingkungan

Biasanya klien merasa ditolak dan mengalami masalah interaksi dengan lingkungan

12. Pengetahuan

Biasanya klien dengan prilaku kekerasan kurang pengetahuan tentang penyakitnya,dan klien tidak mengetahui akibat dari putus obat dan fungsi Dari obat yang diminumnya. 


\subsubsection{Diagnosa Keperawatan}

Berdasarkan pohon masalah dari teori (Nursali, Damaiyanti, 2018)) bahwa perilaku kekerasan disebabkan oleh halusinasi pendengaran, akan berakibat resiko mencederai diri sendiri dan orang lain, dan lingkungan, dari halusinasi dapat berakibat terjadi mencedarai orang 12 lain. Diagnosa keperawatan yang muncul pada klien dengan perilaku kekerasan, halusinasi pendengaran, isolasi sosial dan harga diri rendah.

\subsubsection{Intervensi Keperawatan}

Rencana tindakan keperawatan pada klien dengan diagnosa gangguan persepsi sensori RPK meliputi pemberian tindakan keperawatan berupa terapi (Sulah, Pratiwi, \& Teguh. 2016) yaitu :

1. Mengontrol perilaku kekerasan dengan cara tarik nafas dalam dan memukul kasur/ bantal

2. Minum obat secara teratur.

3. kontrol perilaku kekerasan dengan cara berbicara baikbaik

4. spiritual

Strategi pelaksanaan pasien dengan risiko perilaku kekerasan ada 4 cara antara lain SP 1 (identifikasi penyebab, tanda-tanda, jenis perilaku kekerasan yang dilakukan dan latihan cara mengontrol perilaku kekerasan secara fisik : tarik nafas dalam dan pukul kasur bantal), SP 2 (Latihan minum obat), SP 3 (Latihan secara verbal 3 cara yaitu mengungkapkan, meminta, dan menolak dengan 
benar), SP 4 (Latihan cara mengontrol perilaku kekerasan dengan berdoa).

\subsubsection{Implementasi Keperawatan}

Implementasi disesuaikan dengan rencana tindakan keperawatan. Pada situasi nyata sering pelaksanaan jauh berbeda dengan rencana, hal ini terjadi karena perawat belum terbiasa menggunakan rencana tertulis dalam melaksanakan tindakan keperawatan. Sebelum melaksanakan tindakan keperawatan yang sudah direncanakan, perawat perlu memvalidasi dengan singkat apakah rencana tindakan masih sesuai dan dibutuhkan klien sesuai dengan kondisinya (here and now). Perawat juga menilai diri sendiri, apakah kemampuan interpersonal, intelektual, tekhnikal sesuai dengan tindakan yang akan dilaksanakan, dinilai kembali apakah aman bagi klien. Setelah semuanya tidak ada hambatan maka tindakan keperawatan boleh dilaksanakan (Sahputra, 2021)

Implementasi dilakukan sesuai intervensi keperawatan pada klien dengan perilaku kekerasan dengan melihat kemampuan kognitif, afektif dan psikomotor klien. Tehnik yang perlu diperhatikan adalah strategi komunikasi, yang harus dilakukan yaitu : bersikap tenang, bicara lambat, bicara tidak dengan cara menghakimi, bicara netral dengan cara yang kongkrit, tunjukkan respek pada klien, hindari intensitas kontak mata langsung, demonstrasikan cara mengontrol situasi tanpa kesan berlebihan, fasilitasi pembicaraaan klien, dengarkan klien, jangan terburu-buru menginterpretasikan, jangan buat janji yang tidak dapat 
perawat sejati. Lingkungan: menyediakan berbagai aktivitas. Tindakan perilaku: membuat kontrak dengan klien mengenai perilaku yang dapat diterima.

\subsubsection{Evaluasi}

Evaluasi adalah proses hasil atau sumatif dilakukan dengan membandingkan respon klien pada tujuan umum dan tujuan khusus yang telah ditentukan.RPK pendengaran tidak terjadi perilaku kekerasan, klien dapat membina hubungan saling percaya, klien dapat mengenal RPKnya, klien dapat mengontrol RPK dari jangka waktu 4×24 jam didapatkan data subjektif keluarga menyatakan senang karena sudah diajarkan teknik mengontrol RPK, keluarga menyatakan pasien mampu melakukan beberapa teknik mengontrol RPK. Data objektif pasien tampak berbicara sendiri saat RPK itu datang, pasien dapat berbincangbincang dengan orang lain, pasien mampu melakukan aktivitas terjadwal, dan minum obat secara teratur ( Aji, 2019 )

Evaluasi keperawatan yang diharapkan: klien sudah dapat mengidentifikasi penyebab, frekuensi perilaku kekerasan dan mengontrol perilaku kekerasan dengan Tarik nafas dalam dan pukul kasur atau bantal, klien tidak melakukan perilaku kekerasan, klien minum obat dengan benar dan teratur,pengawas yang ada di yayasan pemenang jiwa sumatera sudah mampu merawat klien, pengawas mengetahui cara minum dan dosis obat klien, pengawas mengetahui kegiatan yang dapat dilakukan klien saat diyayasan pemenang jiwa sumatera. 


\section{BAB 3 \\ TINJAUAN KASUS}

\subsection{Identitas Klien}

$\begin{array}{ll}\text { Inisial } & : \text { Ny. R } \\ \text { Alamat } & : \text { Jln. Anggrek Simpang selayang no.76 } \\ \text { Tanggal Pengkajian } & : \text { 25 Februari 2021 } \\ \text { Umur } & : \text { 31Tahun } \\ \text { Agama } & : \text { Kristen Protestan } \\ \text { Status } & : \text { Belum Menikah } \\ \text { Infoment } & : \text { Status pasien dan komunikasi dengan pasien }\end{array}$

\subsection{Keluhan Utama}

Keluhan klien masuk ke yayasan pemenang jiwa yaitu klien suka marahmarah dirumah dan suka berbicara sendiri

\subsection{Faktor Predisposisi}

Klien pernah mengalami gangguan jiwa selama 5 tahun yang lalu. Tidak ada anggota yang mengalami gagguan jiwa. Dalam keluarga hanya pasien yang mengalami gangguan jiwa.

Masalah keperawatan : Resiko Perilaku Kekerasan

\subsection{Fisik}

Pada saat dilakukan pemeriksaan fisik klien tidak memiliki keluhan, dan saat dilakukan TTV didapatkan hasil :

- TD:120/80 mmHg

- $\quad$ HR: 84 x/menit

- Temp: 36,7 0C

- RR: 24x/menit

- TB: $158 \mathrm{~cm}$ 
- BB: $67 \mathrm{~K}$

\subsection{Psikososial}

\subsubsection{Genogram}

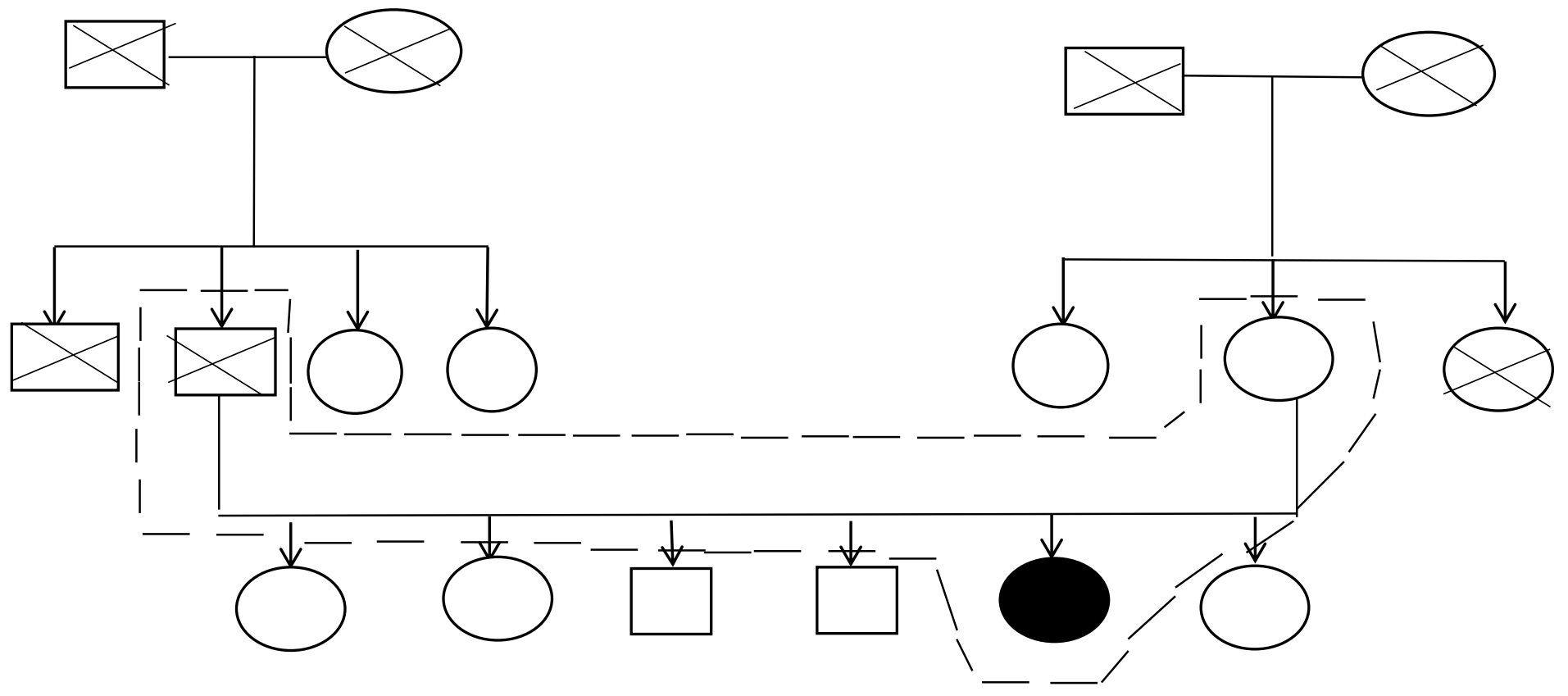

Keterangan :

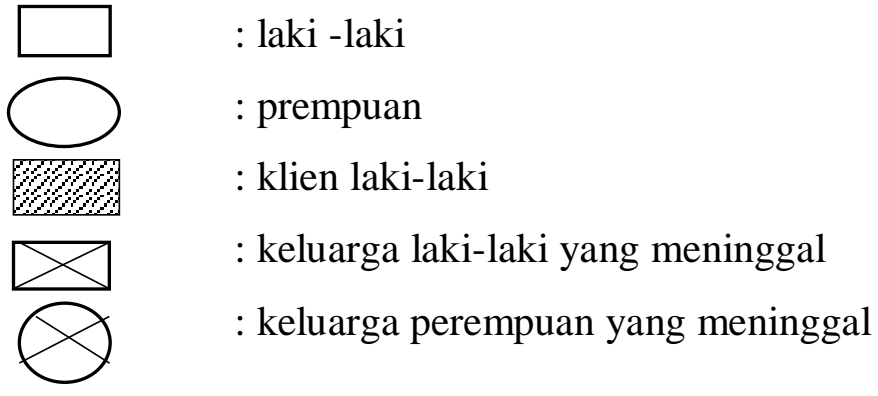

Penjelasan : klien tinggal di Yayasan Pemenang Jiwa Sumatera sudah 5 tahun dengan alasan keluarga membawa klien karana sering marah - marah dirumah . 


\subsubsection{Konsep Diri}

a) Gambaran diri

Klien menyukai seluruh tubuhnya dan tidak ada yang cacat

b) Identitas

Klien anak ke 5 dari 6 bersaudara, klien hanya lulusan SMP yang saat ini tidak memiliki pekerjaan

c) Peran

Klien berperan sebagai anak dikeluarga, klien tinggal bersama keluarganya

d) Ideal diri

Klien merasa malu karena klien dirawat di Yayasan Pemenang Jiwa Sumatera dan ingin cepat pulang ke rumah.

e) Harga diri

Klien merasa tidak berarti lagi di keluarga karena tidak menikah, sehingga keluarga mengasingkan, klien mengatakan merasa bosan berada di Yayasan Pemenang Jiwa Sumatera

Masalah keperawatan : Harga Diri Rendah

\subsubsection{Hubungan Sosial}

a) Orang yang berarti

Klien mengatakan bahwa keluarganya adalah orang yang sangat berarti baginya terutama ibunya, pasien juga mengatakan menyesal telah berperilaku tidak baik pada keluarganya di rumah.

b) Peran serta dalam kegiatan kelompok/masyarakat

Klien mengatakan tidak mengikuti kegiatan di masyarakat tetapi mengikuti kegiatan kelompok seperti beribadah

c) Hambatan dalam berhubungan dengan orang lain

Klien mengatakan sulit berinteraksi dan bersosial di luar lingkungan yayasan karena diawasi sangat ketat. Tetapi untuk berinteraksi di dalam yayasan pasien mengatakan tidak memiliki hambatan 


\subsubsection{Spritual}

1) Nilai dan Keyakinan : klien beragama kristen protestan dan yakin dengan agama yang dianutnya.

2) Kegiatan Ibadah : Selama dirawat diyayasan pemenang jiwa klien selalu mengikuti kegiatan beribadah terjadwal setiap harinya.

\subsubsection{Status Mental}

a) Penampilan

Penampilan pasien rapi seperti berpakaian biasa pada umumnya.

b) Pembicaraan

Klien berbicara lambat dan pandangan kebawah.

c) Aktivitas motoric

Klien mengatakan bisa melakukan aktivitas sehari-hari.

d) Alam perasaan

Klien tidak mampu megespresikan perasaan sesuai kondisi pada saat emosi.

Masalah keperawatan : Risiko Perilaku Kekerasan

e) Afek

klien merespon saat di panggil tetapi pandangan kebawah.

Masalah Keperawatan : Risiko Perilaku Kekerasan.

f) Interaksi selama wawancara

Selama diwawancara pasien bersifat koperatif.

g) Proses Pikir

Klien mampu berbicara sesuai topik pembicaraan dan dapat merespon umpan balik dan dapat mengulang hal penting yang disampaikan perawat.

h) Tingkat Kesadaran Pasien tidak mengalami gangguan orientasi, pasien mengenali, waktu, orang dan tempat. 
i) Memori

Klien mampu mengingat kejadian-kejadian saat melakukan pemukulan kepada ibunya

Masalah Keperawata : Risiko Perilaku Kekerasan.

j) Tingkat Konsentrasi dan berhitung

Klien mampu menjawab pertanyaan berupa hitungan sederhana

k) Kemampuan penilaian

Klien dapat membedakantempat yang bersih dan kotor. Daya tilik diri Pasien mengatakan sadar dirinya mengalami gangguan jiwa, namun pasien menggikarinya.

Masalah Keperawatan : Harga Diri Rendah

\subsection{Kebutuhan Persiapan Pulang}

1. Makan, Minum, BAB/BAK

Klien dapat mengambil makan dan minum dan dapat kekamar mandi untuk BAB/BAK secara mandiri.

2. Mandi, Berpakaian/berhias

Klien megatakan mampu untuk mandi dan berpakaian secara mandiri.

3. Istrahat dan tidur

Tidur Siang pukul13.00 wib s/d 16.30 wib,Tidur malam pukul 22.00 wib s/d 05.00 wib, Kegiatan sebelum/sesudah : Beribadah sesuai jadwal dan mengikuti jalan santai.

\subsection{Mekanisme Koping}

Klien mengatakan jika pada saat klien emosi selalu marah-marah dan ingin memukul Masalah Keperawatan : Risiko Perilaku Kekerasan 


\subsection{Masalah Psikososial Dan Lingkungan}

Masalah dengan dukungan kelompok, spesifik : klien megatakan dukungan psikososial dan lingkungan di Yayasan Pemenang Jiwa Sumatera sangat baik

\subsection{Pengetahuan Kurang Tentang}

Klien mengatakan jika sedang emosi dia delalu marah-marah dan ingin memukul sesuatu, namun pasien tidak tau tentang gangguan jiwa yang dialaminya dan hanya mengetahui bahwa ada obat yang harus terus di konsumsi ketika pengawas di yayasan sudah memerintahkannya. Masalah Keperawatan : Risiko Perilaku Kekerasan.

\subsection{Aspek Medis}

Diagnosa Medik :

1. Risiko Perilaku Kekerasan

2. Halusinasi Pendengaran

3. Harga Diri Rendah

Terapi Medik :

1. Pemberian/minum obat kepada pasien secara teratur.

a. Resperidone(RSP) tablet $2 \mathrm{mg} 2 \times 1$

\subsection{Analisa Data}

\begin{tabular}{|c|l|c|}
\hline No & \multicolumn{1}{|c|}{ Identifikasi Data } & Diagnosa Keperawatan \\
\hline 1 & DS : & Resiko perilaku kekerasaan \\
& $\begin{array}{l}\text { Klien mengatakan bahwa dia tidak tau } \\
\text { alasannya kenapa keluarganya } \\
\text { membawa dia ke yayasan, namun } \\
\text { pasien sadar bahwa keluarganya takut } \\
\text { kalau dia marah-marah dirumah }\end{array}$ & \\
\hline
\end{tabular}




\begin{tabular}{|c|c|c|}
\hline & $\begin{array}{l}\text { DO: } \\
\text { Klien tampak memandang orang lain } \\
\text { dengan tatapan seperti bermusuhan dan } \\
\text { mengepalkan tangannya }\end{array}$ & \\
\hline 2 & $\begin{array}{l}\text { DS: } \\
\text { Klien mengatakan sering mendengan } \\
\text { suara bisikan yang menyuruhnya untuk } \\
\text { marah-marah } \\
\text { DO: } \\
\text { Klien tampak senyum-senyum dan } \\
\text { berbicara sendiri }\end{array}$ & Halusinasi pendengaran \\
\hline 3 & $\begin{array}{l}\text { DS: } \\
\text { Klien merasa minder dengan orang } \\
\text { lain yang memiliki pasangan, } \\
\text { DO: } \\
\text { Klien tampak sering menunduk }\end{array}$ & Harga diri rendah \\
\hline
\end{tabular}

\subsection{Daftar Masalah Keperawatan}

a) Resiko Perilaku Kekerasan

b) Halusinasi Pendengaran

c) Harga Diri Rendah

\subsection{Pohon Masalah}

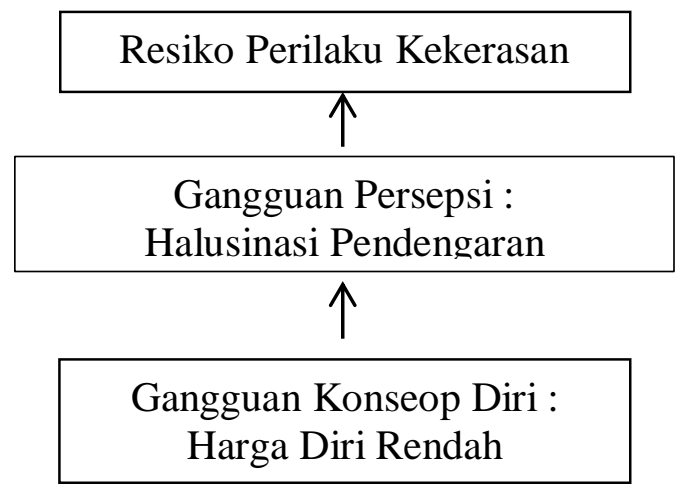




\subsection{Diagnosa Prioritas}

Resiko Perilaku Kekerasan

\subsection{Intervensi Keperawatan}

\begin{tabular}{|c|c|c|}
\hline No & Diagnosa Kep & Inte \\
\hline 1 & $\begin{array}{l}\text { Perilaku kekerasan } \\
\text { DS: } \\
\text { Pasien mengatakan bahwa dia } \\
\text { suka marah-marah dan } \\
\text { bawaanya ingin memukul orang } \\
\text { lain } \\
\text { DO: } \\
\text { Klien tampak memandang orang } \\
\text { lain dengan tatapan seperti } \\
\text { bermusuhan dan mengepalkan } \\
\text { tangannya }\end{array}$ & $\begin{array}{l}\text { Sp } 1 \\
\text { Mengontrol perilaku kekerasan } \\
\text { dengan cara tarik nafas dalam dan } \\
\text { memukul kasur/ bantal } \\
\text { Sp } 2 \\
\text { Kontrol perilaku kekerasan dengan } \\
\text { cara meminum obat secara teratur } \\
\text { Sp } 3 \\
\text { kontrol perilaku kekerasan dengan } \\
\text { cara berbicara baik-baik } \\
\text { Sp } 4 \\
\text { Spritual }\end{array}$ \\
\hline 2 & $\begin{array}{l}\text { Halusinasi } \\
\text { DS: } \\
\text { Klien mengatakan sering } \\
\text { mendengar bisik-bisikan yang } \\
\text { menyuruhnya untuk marah- } \\
\text { marah }\end{array}$ & $\begin{array}{l}\text { Sp } 1 \\
\text { Mengidentifikasi isi, frekuensi, } \\
\text { waktu terjadi, situasi pencetus, } \\
\text { perasaan dan respon halusinasi. } \\
\text { Mengontrol halusinasi dengan cara } \\
\text { menghardik }\end{array}$ \\
\hline
\end{tabular}




\begin{tabular}{|c|c|c|}
\hline & dan berbicara sendiri & $\begin{array}{l}\text { meminum oabat secara teratur } \\
\text { Sp } 3 \\
\text { Mengontrol halusinasi dengan cara } \\
\text { berbicara-bicara dengan orang lain } \\
\text { Sp } 4 \\
\text { Mengontrol halusinasi dengan cara } \\
\text { melakukan kegiatan terjadwal }\end{array}$ \\
\hline 3 & $\begin{array}{l}\text { Harga Diri Redndah } \\
\text { DS: } \\
\text { Pasien merasa minder dengan } \\
\text { orang lain yang memiliki } \\
\text { pasangan, } \\
\text { DO: } \\
\text { Pasien tampak sering menunduk }\end{array}$ & $\begin{array}{l}\text { Sp } 1 \\
\text { Mengidentifikasi kemampuan dan } \\
\text { aspek positif yang dimiliki oleh } \\
\text { pasien } \\
\text { Sp } 2 \\
\text { - Menilai kemampuan yang } \\
\text { digunakan } \\
\text { Menetapkan/ } \\
\text { kegiatan sesuai kemampuan } \\
\text { Melatih kegiatan sesuai } \\
\text { kemampuan yang dipilih } \\
\text { Sp } 3 \quad \text { kemiliki } \\
\text { Melatih } \\
\text { kemampuan yang dipilih } 2 \\
\text { Melatih kegiatan } \\
\text { kempuan yang dipilih } 3\end{array}$ \\
\hline
\end{tabular}




\subsection{5 implementasi dan evaluasi keperawatan}

\begin{tabular}{|c|c|c|}
\hline $\begin{array}{c}\text { Hari / } \\
\text { Tanggal }\end{array}$ & Implementasi & Evaluasi \\
\hline $\begin{array}{l}\text { Selasa, } \\
16 \\
\text { maret } \\
2021 \\
10.00 \\
\text { wib }\end{array}$ & $\begin{array}{l}\text { 1.Data: } \\
\text { Tanda dan gejala : mudah marah, } \\
\text { tatapan sinis, mudah tersinggung } \\
\text { suka menyendiri, dan merasa tidak } \\
\text { dihargai } \\
\text { 2.Diagnosa Keperawatan : } \\
\text { - } \text { risiko perilaku kekerasan } \\
\text { - } \text { halusinasi } \\
\text { - harga diri rendah } \\
\text { 3.Tindakan Keperawatan: } \\
\text { SP 1 Risiko Perilaku Kekerasan } \\
\text { - mengidentifikasi penyebab risiko } \\
\text { perilaku kekerasan yaitu jika } \\
\text { kemauan klien tidak diturutin } \\
\text { - mengidentifikasi tanda dan } \\
\text { gejala risiko perilaku kekerasan } \\
\text { yaitu pasien marah, mengamuk } \\
\text { tanpa alasan yang jelas, merusak } \\
\text { barang-barang dan cenderung } \\
\text { melukai orang lain } \\
\text { - menyebutkan cara mengontrol } \\
\text { risiko perilaku kekerasan dengan } \\
\text { latihan fisik: }\end{array}$ & 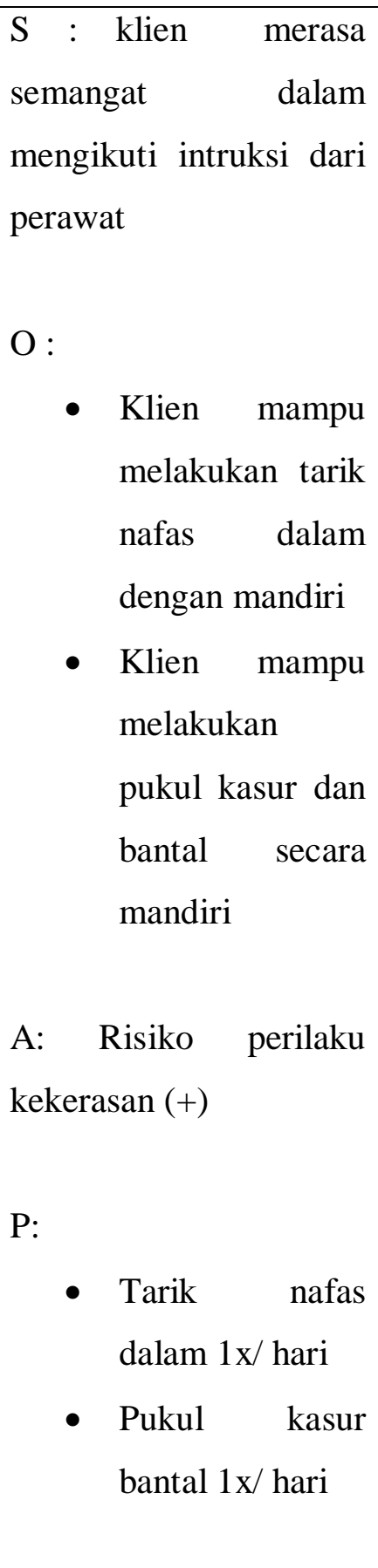 \\
\hline
\end{tabular}




\begin{tabular}{|c|c|c|}
\hline & $\begin{array}{l}\text { a) tarik nafas dalam } \\
\text { b) pukul kasur bantal } \\
\text { - Membantu klien tarik nafas } \\
\text { dalam dan pukul kasur bantal } \\
\text { 4.RTL } \\
\text { SP 2 Risiko Perilaku Kekerasan } \\
\text { - Mengontrol perilaku kekerasan } \\
\text { dengan cara minum obat secara } \\
\text { teratur }\end{array}$ & \\
\hline $\begin{array}{c}\text { Kamis } \\
18 \\
\text { maret } \\
2021 \\
11.00 \\
\text { wib }\end{array}$ & $\begin{array}{l}\text { 1.Data } \\
\text { Tanda dan gejala : mudah marah, } \\
\text { tatapan sinis, mudah tersinggung } \\
\text { suka menyendiri, dan merasa tidak } \\
\text { dihargai } \\
\text { 2.Diagnosa Keperawatan } \\
\text { - Risiko Perilaku Kekerasan } \\
\text { 3.Tindakan Keperawatan } \\
\text { SP 2 Risiko Perilaku Kekerasan } \\
\text { - Mengevaluasi kemampuan klien } \\
\text { untuk tarik nafas dalam dan } \\
\text { pukul kasur bantal } \\
\text { - Memberikan } \\
\text { SP } 3 \text { Risiko perilaku kekerasan }\end{array}$ & $\begin{array}{ll}\text { O : } & \\
\text { - } & \text { Klien mampu } \\
& \text { melakukan } \\
& \text { teknik relaksasi } \\
& \text { nafas dalam } \\
\text { - } & \text { Klien mampu } \\
& \text { pukul kasur/ } \\
& \text { bantal secara } \\
& \text { mandiri } \\
& \text { Klien mampu } \\
& \text { mengontrol } \\
& \text { dengan cara } \\
& \text { minum obat } \\
& \text { secara teratur }\end{array}$ \\
\hline
\end{tabular}




\begin{tabular}{|c|c|c|}
\hline & $\begin{array}{l}\text { - Komunikasi secara verbal : } \\
\text { asertif / berbicara baik-baik }\end{array}$ & $\begin{array}{l}\text { A : Risiko perilaku } \\
\text { kekerasan (+) } \\
\text { P : } \\
\text { - Latihan tarik } \\
\text { nafas dalam dan } \\
\text { pukul kasur } \\
\text { bantal 1x/ hari } \\
\text { - Minum obat } \\
\text { secara teratur } \\
\text { Klien mampu } \\
\text { melakukan } \\
\text { komunikasi } \\
\text { secara verbal : } \\
\text { asertif/ berbicara } \\
\text { baik-baik }\end{array}$ \\
\hline $\begin{array}{c}\text { Selasa } \\
22 \\
\text { maret } \\
2021 \\
10.00 \\
\text { wib }\end{array}$ & $\begin{array}{l}\text { 1.Data } \\
\text { Tanda dan gejala : mudah marah, mudah } \\
\text { tersinggung, dan suka menyendiri } \\
\text { Kemampuan yang dimiliki : menyapu } \\
\text { halaman dan mencuci baju } \\
\text { 2.Diagnosa Keperawatan } \\
\text { - Resiko Perilaku Kekerasan } \\
\text { 3.Tindakan Keperawatan } \\
\text { SP } 4 \text { Risiko Perilaku Kekerasan } \\
\text { • Mengevaluasi }\end{array}$ & $\begin{array}{l}\mathrm{S}: \text { klien merasa senang } \\
\text { dan bersemangat } \\
\mathrm{O}: \text { klien mampu } \\
\text { melaksanakan } \\
\text { beribadah dengan baik } \\
\text { A : Resiko perilaku } \\
\text { kekerasan (+) } \\
\text { P : } \\
\text { - Latihan tarik }\end{array}$ \\
\hline
\end{tabular}




\begin{tabular}{|c|c|c|}
\hline $\begin{array}{l}\text { pasien dalam melakukan teknik } \\
\text { relaksasi nafas dalam, pukul } \\
\text { kasur / bantal, minum obat } \\
\text { secara teratur, dan berbicara } \\
\text { baik-baik } \\
\text { - Melatih pasien untuk } \\
\text { melaksanakan kegiatan spiritual } \\
\text { yang sudah diatur } \\
\text { 4.RTL } \\
\text { Risiko perilaku kekerasan : follow up } \\
\text { dan evaluasi SP 1-4 Resiko perilaku } \\
\text { kekerasan }\end{array}$ & $\bullet$ & $\begin{array}{l}\text { nafas dalam dan } \\
\text { pukul kasur } \\
\text { bantal } \\
\text { Minum obat } \\
\text { secara teratur } \\
\text { Latihan } \\
\text { melakukan } \\
\text { komunikasi } \\
\text { secara verbal : } \\
\text { asertif } \\
\text { berbicara baik- } \\
\text { baik } \\
\text { Latihan klien } \\
\text { untuk } \\
\text { melaksanakan } \\
\text { kegiatan } \\
\text { spiritual }\end{array}$ \\
\hline
\end{tabular}




\section{BAB 4 \\ PEMBAHASAN}

Setelah penulis melakukan asuhan keperawatan kepada Ny. R denga Risiko perilaku kekerasan di yayasan pemenang jiwa sumatera, maka penulis pada BAB ini akan membahas kesenjangan antara teoritid dan tinjauan kasus. Pembahasan dimulai dari tahapan proses keperawatan yaitu : pengkajian, diagnose keperawatan, intervensi, implementasi, dan evaluasi.

\subsection{Tahap Pengkajian}

Selama pengkajian dilakukan pengumpulan data dari beberapa sumber yaitu dari pasien dan pengawas yayasan. Mahasiswa mendapat sedikit kesulitan dalam mmenyimpulkan data kerena keluarga pasien jarang mengkunjungi pasien di yayasan pemenang jiwa. Maka mahasiwa melakukan pendekatan pada pasien melalui komunikasi terapeutik yang lebih terbuka membantu pasien untuk memecahkan perasaannya dan juga melakukan observasi kepada pasien. Adapun upaya tersebut yaitu :

1. Melakukan pendekatan dan membina hubungan saling percaya diri pada klien agar klien lebih terbuka dan lebih percaya dengan menggunakan perasaan.

2. Mengadakan pengkajian pasien dengan wawancara dan tidak menemukan kesenjangan karena di temukan hal sama seperti diteori bahwasanya Perilaku kekerasan merupakan respon maladaptif dari kemarahan, hasil dari kemarahan yang ekstrim ataupun panik. Perilaku kekerasan yang timbul pada klien skizofrenia diawali dengan adanya perasaan tidak berharga, takut,dan ditolak oleh lingkungan sehingga individu akan menyingkir dari hubungan interpersonal dengan oran lain (Pardede, Keliat \& Yulia, 2015). 


\subsection{Diagnosa Keperawatan}

Perencanaan dalam proses keperawatan lebih di kenal dengan asuhan keperawatan yang merupakan tahap selanjutnya setlah pengkajian dan penentuan diagnosa keperawatan. Pada tahap perencanaan mahasiswa hanyamenyusun rencan tindakan keperawatan Risiko Perilaku Kekerasan dan Perilaku Kekerasan. Pada tahap ini antara tinjauan teroritis dan tinjauan kass tidak ada kesenjangan sehingga mahasiswa dapat melaksanakan tindakan seobtimal mungkin di dukung dengan seringnya bimbingan dengan pembimbing. Secara teoritis digunakan secara strategi pertemua sesuai dengan diagnosa keperawatan yang muncul saat pengkajian. Adapun upaya yang digunakan mahasiswa ialah :

\section{Risiko Perilaku Kekersan}

a) Mengidentifikasi isi Risiko Perilaku Kekerasan

b) Mengidentifikasi waktu terjadi Risiko Perilaku Kekerasan

c) Mengidentifikasi situasi pencetus Risiko Perilaku Kekerasan

d) Mengidentifikasi respon terhadap Risiko Perilaku Kekerasan

e) Membantu pasien mempraktekan latihan cara mengontrol Risiko Perilaku Kekerasan dengan tarik napas dalam dan pukul kasur bantal

f) Menjelaskan cara mengontrol perilaku kekerasan dengan minum obat

g) Melatih pasien mengontrol Risiko Perilaku Kekerasandengan berbicara baik-baik dengan orang lain dan spritual

h) Mengevaluasi jadwal kegiatan harian pasien

\subsection{Tahap Implementasi}

Pada tahap implementasi, penulis hanya mengatasi 1 masalah keperawatan yakni: diagnosa keperawatan Risiko Perilaku Kekerasandi 
karenakan masalah utama yang dialami klien. Pada diagnosa keperawatan Risiko Perilaku Kekerasan dilakukan strategi pertemuan yaitu mengidentifikasi Perilaku Kekerasan, mengontrol perilaku kekerasan dengan cara tarik napas dan pukul kasur bantal. Strategi pertemuan yang kedua yaitu anjurkan minum obar secara teratur, strategi pertemuan ketiga yaitu latihan dengan carakomunikasi secara verbal atau bicara baik-baik strategi pertemuan ke empat yaitu Spritual.

\subsection{Tahap Evaluasi}

Pada tinjauan teoritis evaluasi yang diharapkan adalah :

1. klien mempercayai perawat sebagai terapis

2. klien dapat mengidentifikasi dan mengontrol risiko perilaku pekerasan

3. klien dapat mengendalikan risiko perilaku kekerasan melalui latihan fisik

4. klien dapat mengendalikan risiko perilaku kekerasan dengan cara minum obat secara teratur

5. klien dapat mengendalikan risiko perilaku kekerasan dengan berbicara baik-baik

6. klien dapat mengendalikan risiko perilaku kekerasan dengan spritual yang terjadwal.

Pada tinjauan kasus evaluasi yang dihasilkan adalah :

1. klien sudah dapat mengontrol dan mengidentifikasi risiko perilaku kekerasan

2. klien dapat mengidentifikasi tanda-tanda perilaku kekerasan

3. klien dapat menyebutkan jenis perilaku kekerasan yang pernah dilakukanya 
4. klien dapat menyebutkan akibat dari perilaku kekerasan yang dilakukkannya

5. klien dapat menyebutkan cara mencegah/mengontrol perilaku kekerasannya

6. klien dapat menyebutkan cara mencegah/mengontrol perilaku kekerasannya secara fisik, spritual. sosial, dan dengan terapi psikofarmaka. 


\section{BAB 5 \\ PENUTUP}

\subsection{Kesimpulan}

Setelah menguraikan tentang proses keperawatan pada $\mathrm{Ny}$. $\mathrm{R}$ dan disimpulkan bahwa pasien mampu mengontrol risiko perilaku kekerasan dengan terapi yang diajarkan oleh mahasiswa. Dimana klien dapat melakukan teknik relaksasi nafas dalam, memukul bantal untuk mengontrol amarahnya, klien juga minum obat secara teratur, berbicara baik-baik serta kalien dapat melakukan kegiatan spiritual sesuai ajaran agama yang dianut.

\subsection{Saran}

Diharapkan pada pihak keluarga pasien unuk sering mengunjungi pasien selama waktu perawatan karena dengan seringnya keluarga berkunjung, maka pasien merasa berarti dan dibutuhkan dan juga setelah pulang keluarga harus memperhatikan obat yang dikonsumsi serta membawa pasien kontrol secara teratur kepelayanan kesehatan jiwa ataupun rumah sakit jiwa. 


\section{DAFTAR PUSTAKA}

1. Pardede, J. A., Siregar, L. M., \& Hulu, E. P. (2020). Efektivitas Behaviour Therapy Terhadap Risiko Perilaku Kekerasan Pada Pasien Skizofrenia Di Rumah Sakit Jiwa Prof. Dr. Muhammad Ildrem Provsu Medan. Jurnal Mutiara Ners, 3(1), 8-14. http://114.7.97.221/index.php/NERS/article/ view/1005

2. Pitayanti, A., \& Hartono, A. (2020). Sosialisasi Penyakit Skizofrenia Dalam Rangka Mengurangi Stigma Negatif Warga di Desa Tambakmas KebonsariMadiun. Journal of Community Engagement in Health,3(2), 300-303. https://jceh.org/index.php/JCEH/article/view/83/78

3. Kemenkes RI. (2019). Riset Kesehatan Dasar, RISKESDAS.Jakarta: Kemenkes RI. https://databoks.katadata.co.id/datapublish/2019/10/08/persebaran-prevalensi$\underline{\text { skizofreniapsikosis-di-indonesia\# }}$

4. Pardede, J. A., Simanjuntak, G. V., \& Laia, R. (2020). The Symptoms of Risk of Violence Behavior Decline after Given Prgressive Muscle Relaxation Therapy on Schizophrenia Patients. Jurnal Ilmu Keperawatan Jiwa,3(2), 91-100. http://dx.doi.org/10.32584/jikj.v3i2.534

5. Yasa, I. (2020). Gambaran asuhan keperawatan pemberian terapi aktivitas kelompok stimulasi persepsi sesi III: menggunakan rasa marah secara verbal untuk mengatasi risiko perilaku kekerasan pada pasien skizoferenia di UPTD Rsj Dinkes provinsi bali tahun 2020 http://repository.poltekkes-denpasar.ac.id/id/eprint/5031

6. Suryenti, V. (2017). Dukungan Dan Beban Keluarga Dengan Kemampuan Keluarga Merawat Pasien Resiko Perilaku Kekerasan Di Klinik Jiwa Rumah Sakit Jiwa Provinsi Jambi Tahun 2017. Jurnal Psikologi Jambi, 2(2), 39-46. https://www.online-journal.unja.ac.id/jpj/article/view/4795

7. Kandar, K., \& Iswanti, D. I. (2019). Faktor Predisposisi dan Prestipitasi Pasien Risiko Perilaku Kekerasan. Jurnal Ilmu Keperawatan Jiwa, 2(3), 149-156. http://dx.doi.org/10.32584/jikj.v2i3.226

8. Putri, M., Arif, Y., \& Renidayati, R. (2020). Pengaruh Metode Student Team Achivement Division Terhadap Pencegahan Perilaku Kekerasan. Media Bina Ilmia, 14(10), 3317-3326. http://ejurnal.binawakya.or.id/index.php/MBI/article/view/554/pdf

9. Pardede, J. A., \& Laia, B. (2020). Decreasing Symptoms of Risk of Violent Behavior in Schizophrenia Patients Through Group Activity Therapy. Jurnal Ilmu Keperawatan Jiwa, 3(3), 291-300. http://dx.doi.org/10.32584/jikj.v3i3.621 
10. Hastuti, R. Y., Agustina, N., \& Widiyatmoko, W. (2019). Pengaruh restrain terhadap penurunan skore panss EC pada pasien skizofrenia dengan perilaku kekerasan. Jurnal Keperawatan Jiwa, 7(2), 135-144. https://jurnal.unimus.ac.id/index.php/JKJ/article/view/4907/pdf

11. Sujarwo, S., \& Livana, P. H. (2019). Studi Fenomenologi: Strategi Pelaksanaan Yang Efektif Untuk Mengontrol Perilaku Kekerasan Menurut Pasien Di Ruang Rawat Inap Laki Laki. Jurnal Keperawatan Jiwa, 6(1), 29-35. https://doi.org/10.26714/jkj.6.1.2018.29-35

12. Mellia, T. P. F. I. E. T. A. (2020).Asuhan Keperawatan Pada Pasien Skizofrenia Dengan Masalah Resiko Perilaku Kekerasan Di Rumah Sakit Jiwa Daerah Dr Arif Zainudin Surakarta. Diss iversitas Muhammadiyah Ponorogo, 2020. http://eprints.umpo.ac.id/id/eprint/6134.

13. Keliat, B.A \& Akemat (2016). Keperawatan jiwa : terapi Aktivitas kelompok. Ed.2. EGC

14. Parwati, I. G., Dewi, P. D., \& Saputra, I. M. (2018). Asuhan Keperawatan Perilaku Kesehatan. https://www.academia.edu/37678637/asuhan_keperawatan_perilaku_kekerasan

15. Nursaly, E., \& Damaiyanti, M. (2018). Analisis Praktik Klinik Keperawatan pada Tn. E Resiko Perilaku Kekerasan dengan Intervensi Inovasi Terapi Berkebun dengan Polybag terhadap Tanda-Tanda Gejala Resiko Perilaku Kekerasan di RSJD Atma Husada Mahakam Samarinda. https://dspace.umkt.ac.id//handle/463.2017/571

16. Pardede, J. A., Siregar, L. M., \& Halawa, M. (2020). Beban dengan Koping Keluarga Saat Merawat Pasien Skizofrenia yang Mengalami Perilaku Kekerasan. Jurnal Kesehatan, 11(2), 189-196. http://dx.doi.org/10.26630/jk.v11i2.1980 